\title{
MY018A wt Allele
}

National Cancer Institute

\section{Source}

National Cancer Institute. MY018A wt Allele. NCI Thesaurus. Code C98027.

Human MYO18A wild-type allele is located in the vicinity of $17 q 11.2$ and is approximately $107 \mathrm{~kb}$ in length. This allele, which encodes unconventional myosin-XVIIIa protein, plays a role in the modeling of the cytoskeleton. 